\title{
O Ceticismo em Hume
}

Caio Cesar Cabral (DF/USP/SP)

Orientador: João Vergílio Cuter

Muitos comentadores colocam o ceticismo como o cerne da filosofia de Hume. E existem duas tendências básicas de interpretação de sua filosofia: primeiramente a cética, em que Hume nega a realidade objetiva da causalidade, do mundo e do sujeito, e também a naturalista, que ressalta o papel dos instintos e crenças naturais do ser humano.

Esta visão naturalista de sua filosofia existe porque Hume fala muitas vezes dos apelos às forças da natureza, aos instintos e crenças naturais do ser humano. Mas podem os instintos afinal de contas trazer um conhecimento certo sobre as coisas (as qualidades últimas dos objetos, por exemplo)? Nosso filósofo, de qualquer forma, não deixa claro o que entende por "natureza" segundo alguns comentadores, embora a invoque várias vezes.

A interpretação naturalista, então, colocaria o ceticismo como secundário, ou seja, como limitado pela natureza. Já a interpretação cética reverte o quadro, dizendo que o natruralismo é um dos aspectos de um ceticismo fiel ao quadro pirrônico tradicional. Hume, na verdade, seria um cético pirrônico radical, ameaçando destruir até mesmo o programa naturalista.

Estamos, portanto, nos detendo nestas duas possibilidades de interpretação, procurando num primeiro momento encontrar no interior da obra do filósofo as passagens em que ele nos mostra mais claramente estas tendências. Detendonos, por ora, no Livro I do Tratado Sobre a Natureza Humana, mais especificamente em sua Quarta e última parte, podemos encontrar textos seus que apresentam vários argumentos céticos a respeito, por exemplo, da razão, ou ainda da existência dos objetos externos, etc. Comecemos, então, por abordar a Seção I, intitulada "Acerca do ceticismo a respeito da razão"

Hume aí nos diz primeiramente que é interessante, ao adotarmos uma crença ou juízo, que possamos formular um novo juízo que controle este primeiro, levandose, pois, em conta todos os acertos e erros no passado a respeito das mais diversas questões. Tudo aquilo que descobrimos por meio da razão e que chamamos conhecimento não é mais que mera probabilidade. E ainda em todos os juízos que formulemos a respeito do conhecimento ou da probabilidade, devemos aplicar uma espécie de correção advinda de um outro juízo, derivado da natureza do próprio entendimento. É verdade que um homem mais culto terá maior segurança de suas opiniões que um homem ignorante, nos diz o filósofo. Mas mesmo a autoridade destas opiniões nunca é absoluta, pois tal homem também terá consciência de seus erros passados e temerá outros no futuro. Surge aí um novo tipo de probabilidade que corrige e regula a primeira, determinando seu justo critério e proporção. Assim como uma demonstração é sujeita ao controle da probabilidade, esta sofre uma ulterior correção por meio de um ato reflexivo do espírito, cujos objetos são a 
natureza do entendimento e o nosso primeiro raciocínio provável.

Ora, levando-se em conta que todas as conclusões e conhecimento a que chego são mera probabilidade e também o fato de que a faculdade que julga é falível e débil, pode surgir ainda uma nova dúvida, ou seja, pode haver erro ao julgar a fidelidade e veracidade de minhas faculdades. Tais dúvidas, então, não deixarão de se suceder umas às outras até que, finalmente, não reste nada da probabilidade originária, por maior que a tenhamos suposto. Estas sucessivas inspeções farão com que a primeira crença finalmente se reduza a nada. A falibilidade natural de meu juízo me faz confiar menos em minhas opiniões, então, que quando me limito a considerar os objetos acerca dos quais raciocino; e ainda quando examino as sucessivas apreciações que efetuo de minhas próprias faculdades, observo que todas as leis da lógica diminuem em seu valor, até que a crença e a evidência se extinguem totalmente.

Agora, no trecho a seguir desta seção, encontraremos uma passagem que mostra que, ao lado de toda tendência considerada cética de Hume, há também uma que muitos chamam de naturalista, pois ele nos diz que se lhe perguntarem se é um destes céticos que afirmam que nosso juízo não possui medida alguma a respeito da verdade ou falsidade de algo, responderia que afinal de contas a natureza nos impulsiona a julgar como a respirar e a sentir, e que tal é uma necessidade absoluta e incontrolável. Hume chega aqui também a qualificar seu ceticismo como ceticismo total, e diz ainda que quem quer que refute este ceticismo, não terá antagonista. Sua real intenção é apenas prevenir para o fato de que todos os raciocínios relativos a causa e efeito derivam do costume, e a crença é um ato da parte sensitiva da natureza e não da cogitativa. Está demonstrado, então, que os prinćípios que nos permitem formular uma decisão sobre qualquer coisa e corrigi-la pela consideração de nosso próprio engenho, levarão a evidência originária a zero. Se a crença fosse um simples ato do pensamento, se destruiria a si própria e levaria a uma suspensão do juízo. Mas a experiência mostra que a crença continua e que esta é uma certa sensação ou maneira particular de conceber que não pode ser destruída por meras idéias e reflexões.

Suponhamos que, diante de alguma questão, ao considerar as impressões da memória e dos sentidos e no conduzir meus pensamentos desde tais impressões até os objetos aos quais estão habitualmente vinculados, sinto que meu pensamento se inclina com maior necessidade para um lado da questão que para o outro. Após essa decisão, examino meu próprio juízo e vejo que, de acordo com experiências passadas, às vezes ele é correto, e às vezes errado (conduzido por princípios ou causas contrárias). Fazendo um balanço de tais causas contrárias, surge uma nova probabilidade e assim sucessivamente, e o constante agir desta forma, esta atividade forçada e artificial do espírito, acaba afetando a imaginação e o pensamento, ou seja, os mesmos princípios não tem o mesmo efeito que quando as idéias são mais naturalmente concebidas, e produzem também outras sensações na imaginação que não derivam de seus juízos e opiniões comuns.

Sabe-se que o esforço do pensamento perturba a atividade dos sentimentos, assim como as emoções atrapalham todo raciocínio ou reflexão. Estas duas ações não podem ocorrer juntas. E a convicção, então, que deriva de um raciocínio sutil diminui em proporção aos esforços da imaginação para penetrar no raciocínio e 
concebê-lo em todas suas partes. Assim como a crença é uma concepção vivaz, pura e fundada em algo fácil e natural.

Este é o verdadeiro estado de coisas, diz logo a seguir Hume, e os argumentos céticos devem ser respeitados, pois são tão fortes quanto os dogmáticos. O cético ,que usa a razão para combater a própria razão, vai diminuindo a força de seu poder regente e ao mesmo tempo a sua própria (os argumentos dogmáticos não se enfraquecem sem que o mesmo ocorra com os argumentos céticos, pois ambos são da mesma classe). A seguir, temos mais uma passagem que podemos destacar e que apresenta mais uma vez a tendência considerada naturalista do filósofo após uma longa argumentação cética : "Portanto, é afortunado que a natureza destrua a tempo a força de todos os argumentos céticos e os impeça de exercer qualquer influência considerável sobre o entendimento" (Tratado, Livro I Quarta parte).

A seguir, na Seção II desta mesma Quarta parte, intitulada "Acerca do ceticismo com respeito aos sentidos", Hume vai tratar das causas que nos induzem a crer na existência dos objetos. Podemos perguntar-nos que causas nos induzem a crer na existência dos corpos. Por que atribuímos aos corpos uma existência continuada, ainda quando não estão presentes aos sentidos, e por quê supomos que tem uma existência distinta do espírito e da percepção. Como o filósofo se alonga um pouco ao considerar tais questões, os elementos mais importantes de seu discurso podem ser resumidos como se segue: A filosofia nos ensina que qualquer impressão é uma percepção e que, portanto, é subjetiva. Com efeito, a partir da impressão não se pode inferir a existência de um objeto como causa da própria impressão, porque o princípio de causa não tem uma validade teórica, como já vimos. A nossa crença na existência independente e contínua dos objetos é fruto da imaginação, que uma vez ingressando em determinada ordem de idéias, prossegue espontaneamente nessa ordem.

Em especial, como se encontra certa uniformidade e coerência em nossas impressões, a imaginação tende a considerar tal uniformidade e coerência como total e completa, supondo precisamente a existência de corpos que seriam a sua causa. Vejamos um exemplo: eu saio de minha sala e, desse modo, deixo de ter todas as impressões que constituem esta minha sala; depois de certo tempo, ao retornar, tenho as mesmas impressões de antes ou, de todo modo, tenho percepções parcialmente iguais às de antes e em parte diferentes, mas coerentes com elas (por exemplo, encontro a luz reduzida por que já se fez tarde ou encontro o fogo da lareira quase extinto porque a lenha já queimou toda).

Pois bem, a imaginação preenche o vácuo da minha ausência, supondo que essas percepções correspondentes e coerentes em relação às anteriores correspondam a uma existência efetiva e separada dos objetos que constituem a minha sala. E mais: ao trabalho da imaginação se acrescenta ainda o da memória, que dá vivacidade às impressões fragmentadas e intermitentes (por causa de minha saída e da posterior volta à sala). E essa vivacidade gera a crença na existência dos objetos externos correspondentes. Assim, o que se salva da dúvida cética é essa crença instintiva, que é de gênese alógica e arracional.

Assim fizemos, portanto, os primeiros estudos buscando identificar o mais possível as tendências consideradas cética e naturalista do filósofo. Posteriormente, estaremos nos detendo ainda nas demais partes do Tratado, e também na Investi- 
gação, para encontrar na unidade do pensamento do filósofo a evidente conciliação entre estas duas tendências e identificar qual das duas é preponderante nesta teoria do conhecimento humeana.

Notas:

1. Hume, David Tratado de La Naturaleza Humana Acerca del entendimiento Tradução para o espanhol, prólogo e notas de Margarita Costa 1ำ edição, 1974 